\title{
Biochemical Changes During the Reproductive Activity in Male Sand Lobster Thenus orientalis (Lund, 1793)
}

\author{
R. Banumathy ${ }^{1 *}$, M. Padmaja ${ }^{2}$ and M. Deecaraman ${ }^{3}$ \\ 182 Unit of Invertebrate Reproduction \& Pharmacological Endocrinology, Department of Zoology, \\ SirTheagaraya College, Chennai-21; banu3235@gmail.com, padmaja.m779@gmail.com \\ ${ }^{3}$ Dr.M.G.R University, Maduravoyal; drdeecaraman@gmail.com
}

\begin{abstract}
In a situation of increasing anthropogenic activities, assessing their impacts on organisms needs basic information from biological sciences to evaluate the degree of toxicity. Hence, an effort was made to furnish certain vital changes in the biochemical parameters during the reproductive phase in the normal immature and mature male sand lobster Thenus orientalis. The nutrients; protein, carbohydrate and lipid and the enzymes; LDH, NSE, ACP and ALP were estimated and recorded for a deep understanding of the reproductive biology of the taken edible lobster. Highly significant results $(\mathrm{p}<0.01)$ were obtained in the testis, vas deferens and hepatopancreas with reference to their nutrient content. Comparatively, elevated LDH was noted in immature forms. Less difference were found in NSE but among the phosphstases, alkaline type exhibited highly significant values $(\mathrm{p}<0.01)$ in the reproductive tissue indicating its need. The values registered will aid in the future to estimate the level of impact of any habitat toxicant on the biochemical aspects of maturation of the male sand lobster.
\end{abstract}

Keywords: Thenus orientalis, Biochemical Changes, Reproduction, Male Sand Lobster.

\section{Introduction}

The sand lobster, Thenus orientalis is an export oriented and commercially important species [7] and has a wide geographical distribution over Indo-Pacific area from Japan through Philippines to Gulf countries and Australia and the lobster formed a minor fishery as far as Chennai coast is concerned, with the catch trend through the years showing gradual increase, sharp rise and moderate fall [15]. A very few authors have reported the physiology of Thenus orientalis. Jhonston and Alexander [5] have reported the functional morphology of the mouth parts and alimentary tract of Thenus orientalis. The function of digestive gland [6], spermatid and sperm pathway [2] and ultra structure of mature sperm (Wang, 2000) has been recorded but none have attempted the biochemical alterations during the reproductive activity of male specimen which is imperative to comprehend the reproductive dynamics of this export demand species.

\section{Materials and Methods}

\subsection{Study Area and Animal Collection}

For the present study live specimens of male sand lobsters, Thenus orientalis were collected from the commercial catches of Royapuram fishing harbour. The main fishery season appeared to coincide the wet periods, SeptemberFebruary, with peak abundance in October-November and lean fishery generally occurred during the warmer

\footnotetext{
* Corresponding author:
}

R. Banumathy (banu3235@gmail.com) 
months, March-May [15].This was evident in the present study and the male specimen were identified and collected by certain morphological features and was brought immediately to the laboratory in a plastic bucket with sea water and maintained in the laboratory for biochemical analysis. The immature and mature forms were differentiated by dissecting the specimen and observing the features of the testis. The immature testis are very small, thin and creamy white in appearance whereas mature testis are more bulged, highly convoluted and lies in between the hepatopancreas and occupies one third of cephalothoracic region.

\subsection{Biochemical Analysis}

Total Proteins, carbohydrates and lipids were estimated in the testis, vasdeferens, hepatopancreas ,muscle and haemolymph in the immature stage and matured stage of male Thenus orientalis, and also enzyme activity such as lactate dehydrogenase (LDH) non specific esterases, acid phosphatases, and alkaline phosphatase activity were studied.

The protein content of the tissue extracts was estimated by the method adopted by Lowry et al. [11]. The carbohydrate content of the tissue and haemolymph extracts were estimated by the method of Roe [12] and the lipid content were estimated by the recommended method of Barnes and Blackstock [1].

The lactate dehydrogenase activity was estimated by the technique followed by Krajnovic-Ozretic and Ozretic [10].The activity of Non specific esterases was estimated as per the tested method of Van Asperson [17] and the reaction mixture containing substrate, buffer and enzyme was prepared as per the method of Gomori [4]. The activity of acid phosphatase activity was estimated by the procedure of Wooton [21] and the activity of alkaline phosphate was estimated by P-NPP method of Comb and Bowis [3].

Statistical analysis for the biochemical composition for all the tissues of immature stage and matured stage was applied using SPSS package version 11.5 [14].

\section{Results and Discussion}

\subsection{Protein}

The total protein content obtained from the immature stage of the testis, vasdeferens hepatopancreas, muscle and haemolymph are 18.13, 17.38, 20.53, 20.05 and 19.13 respectively. In the maturation stage a different picture of protein content of testis, vasdeferens, hepatopancreas,
Table 1. Quantitative estimation of protein content in the different tissues of immature stage and matured stage of male T. orientalis

\begin{tabular}{lcc}
\hline Tissues & Immature stage & Matured stage \\
\hline Testis & $18.13 \pm 0.621$ & $22.75 \pm 0.467^{\star *}$ \\
Vasdeferens & $17.38 \pm 0.670$ & $23.68 \pm 0.477^{\star *}$ \\
Hepatopancreas & $20.53 \pm 0.682$ & $12.54 \pm 1.109^{\star *}$ \\
Muscle & $20.05 \pm 0.492$ & $22.47 \pm 0.432^{\star *}$ \\
Haemolymph & $9.13 \pm 0.329$ & $9.84 \pm 0.278^{\star}$ \\
\hline
\end{tabular}

muscle and haemolymph were exihibited. They were in the order of 22.75, 23.68, 12.54, 22.47 and 9.84 correspondingly (Table 1). The statistical analysis showed that there is a significant $(\mathrm{P}<0.01)$ increase in the protein content of vasdeferns, testis, muscle and hepatopancreas of matured stage, when compared to the immature stage. Similarly the haemolymph showed a significant increase $(\mathrm{P}<0.05)$ when compared to the immature stage.

\subsection{Carbohydrate}

From the results it is evident that the carbohydrate level rises in the advanced stage of the testis and vas deferens and the carbohydrate content showed a depleting trend in the hepatopancreas and muscle (Table 2).A statistically significant $(\mathrm{P}<0.01)$ increase in carbohydrate content in the maturation stage (testis, vasdeferens and hepatopancreas) were noticed. Similarly a significant result $(\mathrm{P}>0.05)$ in the carbohydrate level of muscle was recorded in the experiment.

\subsection{Lipid}

As per the lipid substance is concerned, a highly significant result $(\mathrm{P}<0.01)$ was obtained in the comparison of the two gonodial developmental stages in the testis, vas deferens, hepatopancreas and haemolymph (Table 3 ).

Table 2. Quantitative estimation of carbohydrate level in different tissues of immature stage and matured stage of male T. orientalis

\begin{tabular}{lcc}
\hline Tissues & Immature stage & Matured stage \\
\hline Testis & $7.70 \pm 0.412$ & $10.74 \pm 0.414^{* *}$ \\
Vasdeferens & $8.78 \pm 0.367$ & $11.43 \pm 0.502^{* *}$ \\
Hepatopancreas & $10.77 \pm 0.419$ & $6.70 \pm 0.447^{\star *}$ \\
Muscle & $10.66 \pm 0.382$ & $9.93 \pm 0.324^{\star}$ \\
Haemolymph & $7.76 \pm 0.380$ & $7.82 \pm 0.381 \mathrm{NS}$ \\
\hline
\end{tabular}


Table 3. Quantitative estimation of lipid level in different tissues of immature stage and matured stage of male T. orientalis

\begin{tabular}{lcl}
\hline Tissues & Immature stage & Matured stage \\
\hline Testis & $16.97 \pm 0.573$ & $23.08 \pm 0.472^{\star *}$ \\
Vasdeferens & $18.15 \pm 0.546$ & $21.80 \pm 0.260^{\star *}$ \\
Hepatopancreas & $21.47 \pm 0.435$ & $14.26 \pm 0.645^{\star *}$ \\
Muscle & $17.84 \pm 0.881$ & $18.75 \pm 0.739 \mathrm{NS}$ \\
Haemolymph & $17.24 \pm 0.619$ & $12.21 \pm 0.740^{\star *}$ \\
\hline
\end{tabular}

For Tables 1, 2 \& 3 .

Each value is mean \pm SEM of 12 samples, expressed as $\mathrm{mg} / \mathrm{gm}$ of wet tissue and $\mathrm{mg} / \mathrm{ml}$ of haemolymph.

Note: ${ }^{*}<<0.05,{ }^{* *} \mathrm{p}<0.01$, NS- Not significant.

\subsection{Study of Enzymes Activity}

With reference to lactate dehydrogenase (LDH) and nonspecific esterase (NSE), a statistically significant result were obtained in almost all the test organs of male Thenus orientalis(Table $4 \& 5$ ). As far as phosphatase quantification is concerned the enzyme acid phosphatase exhibited a significant recording in vas deferens, hepatopancreas and hemolymph. Apart from vas deferens and hepatopancreas, a significant result was found in the testis in the case of alkaline phosphatase enzyme (Table 6).

Table 4. Amount of lactate dehydrogenase enzyme in different tissues in the immature stage and matured stage of male $\mathrm{T}$. orientalis

\begin{tabular}{lcc}
\hline Tissues & Immature stage & Matured stage \\
\hline Testis & $9.66 \pm 0.290$ & $8.42 \pm 0.273^{\star \star}$ \\
Vasdeferens & $9.38 \pm 0.461$ & $8.54 \pm 0.291^{\star}$ \\
Hepatopancreas & $8.61 \pm 0.487$ & $7.78 \pm 0.319^{\star}$ \\
Muscle & $9.97 \pm 0.453$ & $7.69 \pm 0.328^{\star *}$ \\
Haemolymph & $8.43 \pm 0.440$ & $7.49 \pm 0.313^{\star}$ \\
\hline
\end{tabular}

Table 5. Amount of non-specific esterase enzyme in different tissues in the immature stage and matured stage of male T. orientalis

\begin{tabular}{lll}
\hline Tissues & Immature stage & Matured stage \\
\hline Testis & $8.18 \pm 0.354$ & $7.28 \pm 0.505^{\star}$ \\
Vasdeferens & $7.90 \pm 0.392$ & $7.39 \pm 0.591^{\star}$ \\
Hepatopancreas & $7.92 \pm 0.468$ & $6.57 \pm 0.454^{\star}$ \\
Muscle & $8.35 \pm 0.420$ & $8.77 \pm 0.445 \mathrm{NS}$ \\
Haemolymph & $8.54 \pm 0.393$ & $5.42 \pm 0.341^{\star *}$ \\
\hline
\end{tabular}

Table 6. Amount of acid phosphatase enzyme in different tissues in the immature stage and matured stage of male T. orientalis

\begin{tabular}{lcc}
\hline Tissues & Immature stage & Matured stage \\
\hline Testis & $8.04 \pm 0.297$ & $7.69 \pm 0.368 \mathrm{NS}$ \\
Vasdeferens & $7.69 \pm 0.418$ & $10.69 \pm 0.732^{\star *}$ \\
Hepatopancreas & $9.48 \pm 0.560$ & $7.58 \pm 0.411^{\star}$ \\
Muscle & $8.62 \pm 0.535$ & $8.40 \pm 0.406 \mathrm{NS}$ \\
Haemolymph & $6.30 \pm 0.366$ & $7.08 \pm 0.344^{\star}$ \\
\hline
\end{tabular}

Table 7. Amount of alkaline phosphatase enzyme in different tissues in the immature stage and matured stage of male $\mathrm{T}$. orientalis

\begin{tabular}{lrc}
\hline Tissues & Immature stage & \multicolumn{1}{c}{ Matured stage } \\
\hline Testis & $7.22 \pm 0.286$ & $10.93 \pm 0.293^{\star *}$ \\
Vasdeferens & $7.64 \pm 0.336$ & $11.61 \pm 0.638^{\star *}$ \\
Hepatopancreas & $9.94 \pm 0.418$ & $7.30 \pm 0.357^{\star *}$ \\
Muscle & $13.15 \pm 0.480$ & $13.40 \pm 0.567 \mathrm{NS}$ \\
Haemolymph & $6.48 \pm 0.343$ & $6.15 \pm 0.393 \mathrm{NS}$ \\
\hline
\end{tabular}

For Tables 4, 5, 6 \& 7 .

Each value is mean \pm SEM of 12 samples, expressed as $\mu / \mathrm{gm}$ of wet tissue and $\mu / \mathrm{ml}$ of haemolymph.

Note: ${ }^{*} \mathrm{p}<0.05,{ }^{* *} \mathrm{p}<0.01$, NS- Not significant.

\section{Discussion}

Lobsters are sensitive animals and they exhibit elevated levels of certain metabolic substances while handling and $24 \mathrm{hr}$ period is required for the restoration of normal metabolites [13] In addition, lobsters at higher temperatures have greater respiratory requirements and excrete greater amounts of ammonia [16]. With these limitations, sufficient period for restoration were given and optimal temperature conditions were maintained for the estimation of nutrients and metabolic enzymes.

Thenus orientalis has a complex and prolonged life cycle, which often involves several planktonic ("free floating") larval stages [9]. Juveniles are found to have highest LDH activities compared to the matured ones [20].This was apparent in the present investigation with the immature ones recording higher LDH content in all the tested tissue than matured ones indicating higher metabolic pelagic life. Speed et al. (2001) found lactate dehydrogenase to be highest in muscles supporting anaerobic burst activity in lobsters and especially muscle lactates were high in captive animals due to stress. Lactate dehydrogenase catalyzes the 
interconversion of pyruvate and lactate with concomitant interconversion of $\mathrm{NADH}$ and $\mathrm{NAD}+$ to meet the energy requirements.

In the present investigation too highest recording of $\mathrm{LDH}$ was found in the muscles of T.orientalis mainly in the immature forms due to its mode of life. In the immature forms, carbohydrate content was found to be higher in hepatopancreas and muscle establishing as the major organ of carbohydrate metabolism. In the mature ones, testis and vas deferens registered a higher proportion of carbohydrate, proteins and lipids indicating active spermatogenesis and gonodial hormone synthesis. It further suggests that the nutrient contents of hepatopancreas are utilized for ensuring the growth of spermatocytes and subsequent developmental aspects of the individual through sequestration. A similar finding has been reported by Viswanathan [18] on Uca triangularis. With reference to non-specific esterases there was less marked difference between the immature and the mature forms. The acid phosphatase and alkaline phosphatase study reveal that the difference among immature and the mature individuals was not significant whereas vas deferens and testis exhibited a notable result demonstrating a high phosphatase activity involved in reproductive process.

\section{Conclusion}

In biological systems, the biocatalysts play a vital role in the metabolic pathways. Animal alter their physiological status with the help of enzymes [8]. Growth and maturation is an energy demand process. Hence, energy metabolism has to be channelized towards gamete production and related activities during maturation stage. It was highly evident in the present investigation as the nutrient content demonstrated a considerable decrease in hepatopancreas which is considered as one of the energy depot. A relatively high content of phosphatases are found in the matured individuals of crustacean and this is due to the fact that phosphatases are dephosphorylating enzymes, may well be present where any synthesis of phosphorus compounds such as nucleic acids takes place. In reality, spermatogonia are particularly rich in phosphatases during maturation phase, possibly because an active synthesis of nucleic acids occurs in them during successive mitoses and meioses. In general, the findings of the present study are a fundamental and essential baseline data on the reproductive biochemical kinetics which can be utilized for any toxicological investigation with reference to the edible lobster T.orientalis.

\section{References}

1. Barnes, and Blackstock (1973). Estimation of lipids in marine animals and tissues detailed investigation of the phosphovanilin method for total lipids, Journal of Experimental Marine Biology and Ecology, vol 12, 103-118.

2. Burton T E (1995). The spermatid pathway and associated reproductive structure of the squat lobster Thenus orientalis, Invertebrate Reproduction \& Development, vol 28(1), 53-61.

3. Comb Mc RB, and Bowis G M (1972). A Criteria for establishing standard method for determining alkaline phosphatase in serum, Clinical Chemistry, vol 18, 97-108.

4. Gomori (1951). Aldehyde fuchsin: A new stain for elastic tissue. American Journal of Clinical Pathology, vol 20, 665666.

5. Jhonston D J, and Alexander CG (1999). Functional morphology of the mouth parts and alimentary tract of slipper lobster Thenus orientalis, (Decapoda, Scyllariodea), Marine and Freshwater Research, vol 50(3),213-223.

6. Jhonston D J (1998). Relationship between dietary preference and digestive enzymes complement of the slipper lobster, Thenus orientalis (Decapoda: Scyllaridae). Journal of Crustacean Biology, vol 18(4), 656-665.

7. Kagwade P V, and Kabli L M (1996). Reproductive biology of sand lobster Thenus orientalis (Lund) from Bombay waters, Indian Journal of Fisheries, vol 43(1), 13-25.

8. Kalyanaraman and Senthilkumaar (2009). Effect of lead on the expression of nutritional content in edible lobster. Thenus orientalis (Lund, 1793). Indian Journal of Science and Technology, vol 10(2), 17-22.

9. Kizhakudan J K (2005). Culture potential of the sand lobster Thenus orientalis (Lund), International Symposium on improved sustainability of fish production by appropriate technologies for utilization of Sustain Fishery, 16-18.

10. Krajnovic-Ozretic M, and Ozretic B (1987). Estimation of the enzymes LDH, GOT and GPT in plasma of grey mullet Mugil auratus and their significance in liver intoxication, Dis Aquacultural Organisation, vol 3, 187-193.

11. Lowry O H, Rosebrough N J et al. (1951). Protein measurements with folin reagent, The Journal of Biological Chemistry, vol 193, 265-275.

12. Roe J R (1951). The determination of sugar in blood and spinal fluid with anthrone reagent, The Journal of Biological Chemistry, vol 193, 265-275.

13. Speed S R, Baldwin J et al. (2001). Metabolic characteristics of muscles in the spiny lobster, Jasus edwardsii, and responses to emersion during simulated live transport, Comparative Biochemistry and Physiology Part B: Biochemistry and Molecular Biology, vol 128(3), 435-444.

14. SPSS (2004). Step-by-Step, Tutorial: Part 1, version 11.5, Data step development 
15. Subramanian V T (2004). Fishery of sand lobster Thenus orientalis (Lund) along Chennai coast, Indian Journal of Fisheries, vol 51(1), 111-115.

16. Thomas C W, Crear B J et al. (2000). The effect of temperature on survival, growth, feeding and metabolic activity of the southern rock lobster, Jasus edwardsii, Aquaculture, vol 185(1-2), 73-84.

17. Van Asperson K (1962). A study of housefly esterase by means of sensitive colorimetric method, Journal of Insect Physiology, vol 8(4), 401-416.

18. Viswanathan (1992). Studies on the reproduction aspects of a brackish water crab, Uca Triangularis Bengali of Pulicat lake Tamil nadu Ph.D Thesis, University of Madras Chennai.
19. Wang G, Zhu-Dongfa et al. (1998). Preliminary study on the temperature specific rates of embryonic development of the flat head lobster Thenus orientalis Marine Science Bulletien, Haiyanag Tonghao, vol 17, 39-49.

20. Wells R M, Lu J et al. (2001). Ontogenetic changes in enzyme activities associated with energy production in the spiny lobster, Jasus edwardsii, Comparative Biochemistry and Physiology Part B: Biochemistry and Molecular Biology, vol 130(3), 339-347.

21. Wotton I D P (1964). Microanalysis in medical biochemistry, Churchill, Livingstone, New York, vol 3, 432-435.

22. Wang G Z, and Li S J (2000). Sperm Ultrastructure of the Squat lobster, Thenus orientalis (Crustacea, Decapoda), Zoological Research, vol 21(5), 387-391. 